Research, part of a Special Feature on Vulnerability and Adaptation to Oil Spills

\title{
Corporate Social Responsibility or Government Regulation? Evidence on Oil Spill Prevention
}

\author{
Jedrzej G. Frynas $^{1}$
}

\begin{abstract}
Major oil spills normally occur from oil pipelines and oil tankers that are under operational control of companies, namely, oil companies and tanker owners. There are two generic responses for changing the behavior of companies with regard to oil spill prevention: mandatory government regulation or voluntary initiatives often pursued under the banner of Corporate Social Responsibility (CSR). Here we investigate to what extent voluntary CSR initiatives can be effective in oil spill prevention. A global perspective on voluntary mechanisms is taken by looking at the progress of 20 oil and gas firms from around the world toward oil spill prevention, using the companies' 2010 sustainability reports for self-reported oil spill information. The analysis includes ten oil companies from OECD countries (including Exxon and Shell, among others) and 10 oil companies from nonOECD countries (including Brazil's Petrobras and Indian Oil, among others). The study finds that oil spill prevention has generally improved over recent decades. Government regulation played a significant part in these improvements whereas it is less clear to what extent CSR played a significant part in these improvements. Some of CSR's key limitations are highlighted. It is not suggested that CSR should be abandoned; however, new hybrid forms of regulation that combine voluntary and mandatory elements are advocated.
\end{abstract}

Key Words: Corporate Social Responsibility; oil spill prevention; oil spills; petroleum; regulation; voluntary regulation

\section{INTRODUCTION}

Major oil spills normally occur from oil installations and oil tankers that are under operational control of companies, that is, oil companies and tanker owners. There are two generic responses for changing the behavior of companies with regard to oil spill prevention: mandatory government regulation or voluntary initiatives often pursued under the banner of Corporate Social Responsibility (CSR). Here we investigate the potential of voluntary CSR initiatives for preventing oil spills, ask to what extent CSR can be effective and to what extent CSR should supplant or complement mandatory regulation.

The oil and gas sector has been among the leading industries in championing CSR. One explanation is that oil and gas operations pose serious threats to the environment at each stage of the industrial process: construction, exploration, production, transportation, and refining (Clark 1982, Estrada et al. 1997), while multinational oil companies are more vulnerable to civil society pressures than companies in some other sectors of the economy because the negative effects of oil operations are highly visible and because the companies' international brand reputations are vulnerable (Austin and Sauer 2002, Frynas 2009). Another important explanation is that oil companies are willing to accept higher levels of sociopolitical risks as they are forced to operate in more challenging environments for geological reasons, with oil and gas deposits often being located near ecologically vulnerable areas and in countries with poor governance (Pegg 2006, Chen 2007).

The growth of CSR is demonstrated, among others, by the remarkable growth of corporate codes of conduct and social and environmental reporting. A total of $95 \%$ of the world's 250 largest companies formally report on their CSR activities, with oil companies being at the forefront of this reporting movement (KPMG International 2011). CSR has become more sophisticated and complex from the mid 1990s. Oil companies have joined various international voluntary initiatives aimed at addressing different aspects of sustainability, including the Global Reporting Initiative (1997), UN Global Compact (1999), Voluntary Principles on Security and Human Rights (2000), Extractive Industries Transparency Initiative (EITI - 2003) and Combat Climate Change 3C Initiative (2007) (Frynas 2010).

At the same time, CSR has been criticized from different perspectives. On the one hand, some business writers have traditionally asserted that CSR is misguided in principle. According to this view, by pursuing social and environmental objectives, firms may ultimately hurt shareholders by generating lower profits, while firms are said to lack the expertise to engage in solving social and environmental problems (Friedman 1962, Henderson 2001, Ottaway 2001). On the other hand, various studies have pointed to the limitations and relatively poor results of existing CSR initiatives in terms of delivering social and environmental outcomes, including studies that specifically investigated CSR in the oil and gas sector (Pegg 2006, Soares de Oliveira 2007, Frynas 2009, Gillies 2010).

It is therefore pertinent to ask whether the emerging system of voluntary self-regulation has led to genuine improvements in the environmental performance of oil companies. We investigate improvements in oil spill prevention by comparing 
the possible impact of voluntary CSR initiatives vis-à-vis mandatory government regulation (for an overview and timeline, see Table 1).

Table 1. Timeline of key oil spill-relevant CSR initiatives and international mandatory regulation.

\begin{tabular}{|c|c|}
\hline Voluntary CSR initiative & Mandatory government regulation \\
\hline $\begin{array}{l}1969 \text { Tanker Owners' Voluntary } \\
\text { Agreement concerning Liability for } \\
\text { Oil Pollution (TOVALOP) }\end{array}$ & $\begin{array}{l}1969 \text { International Convention on } \\
\text { Civil Liability for Oil Pollution } \\
\text { Damage (CLC) }\end{array}$ \\
\hline $\begin{array}{l}1970 \text { Oil Companies International } \\
\text { Marine Forum (OCIMF) }\end{array}$ & $\begin{array}{l}1971 \text { International Convention on } \\
\text { the Establishment of an International } \\
\text { Fund for Compensation for Oil } \\
\text { Pollution Damage (FUND) }\end{array}$ \\
\hline $\begin{array}{l}1974 \text { Offshore Pollution Liability } \\
\text { Agreement (OPOL) }\end{array}$ & $\begin{array}{l}1973 \text { International Convention for } \\
\text { the Prevention of Pollution From } \\
\text { Ships (MARPOL, in force from } \\
\text { 1983) }\end{array}$ \\
\hline $\begin{array}{l}1993 \text { Ship Inspection Report } \\
\text { Programme (SIRE) }\end{array}$ & $\begin{array}{l}1974 \text { International Convention for } \\
\text { the Safety of Life at Sea (SOLAS) }\end{array}$ \\
\hline $\begin{array}{l}1997 \text { Global Reporting Initiative } \\
\text { (GRI) }\end{array}$ & $\begin{array}{l}1992 \text { MARPOL Amendment on } \\
\text { Prevention of Pollution by Harmful } \\
\text { Substances Carried by Sea in } \\
\text { Packaged Form }\end{array}$ \\
\hline $\begin{array}{l}2005 \text { Oil and gas industry guidance } \\
\text { on voluntary sustainability } \\
\text { reporting }\end{array}$ & $\begin{array}{l}2003 \text { MARPOL Amendment on } \\
\text { Prevention of Pollution by Sewage } \\
\text { from Ships }\end{array}$ \\
\hline
\end{tabular}

The author does not have a strong ideological preference for either voluntary CSR initiatives or mandatory government regulation, and the starting point of this study is simply pragmatic by asking to what extent voluntary CSR initiatives of companies can replace or complement government regulation as the determinant of responsible environmental practices. Based on the available evidence, it is concluded that oil spill prevention has generally improved over recent decades. Government regulation played a significant part in these improvements whereas it is less clear to what extent CSR played a significant part in these improvements. Some of CSR's key limitations are highlighted.

\section{CORPORATE SOCIAL RESPONSIBILITY AND ENVIRONMENTAL MANAGEMENT}

CSR has been evolving over the last three decades alongside related concepts such as accountability and sustainability. However, there is no agreement on what exactly CSR stands for or where the boundaries of CSR lie (Lockett et al. 2006, Blowfield and Murray 2008).

The responsibilities of companies are often defined differently depending on the social, especially national, context
(Waldman et al. 2006, Freeman and Hasnaoui 2011) and the industry context (Frynas 2009, Runhaar and Lafferty 2009). Furthermore, CSR is a dynamic concept and its meaning can change over time (Carroll 1999, Matten and Moon 2008). One recent study concluded that "the definition of CSR is not only inconsistent across national boundaries, but the definitions are not consistent within countries" (Freeman and Hasnaoui 2011:439). Therefore, it is most appropriate to define CSR as an umbrella term for a variety of different theories and practices all of which recognize that companies have a responsibility for their impact on society and the natural environment, that companies have a responsibility for the behavior of others with whom they do business, and that CSR activities are normally conducted on a voluntary basis beyond legal compliance (Blowfield and Frynas $2005 \mathrm{cf}$. Matten and Crane 2005). The voluntary aspect forms the key distinguishing characteristic between CSR and mandatory regulation in that CSR establishes certain standards and rules of behavior that are followed by companies voluntarily, even though there is no mandatory requirement to do so.

CSR encompasses many different areas, ranging from health and safety to human rights, but research consistently suggests that CSR has greatest potential with regard to environmental management (SustainAbility 2001, 2002, Molina-Azorín et al. 2009). The business literature suggests that voluntary environmental initiatives can help to lead to substantial improvements in environmental practices by business such as reduction in the use of materials and emissions, increased recycling or adoption of new environmentally-friendly products, while at the same time the most environmentallyfriendly companies are rewarded with higher profitability (for example, King and Lenox 2002, Molina-Azorín et al. 2009).

On the one hand, business research suggests that companies can benefit from environmental management in terms of a better reputation (differentiation vis-à-vis competitors), lower costs (lower energy and materials use) and innovation (new green products, practices, and patents) (Miles and Covin 2000, Molina-Azorín et al. 2009). On the other hand, business research suggests that management tools, methods, and practices (e.g., quality management or performance management) are particularly suited for environmental improvements because they share similar purposes and approaches to implementation (Frynas 2009:79-80; MolinaAzorín et al. 2009). Therefore, one would expect many companies to voluntarily engage in environmental management and, in turn, to make significant environmental improvements.

The benefits of CSR and environmental management have been explored with specific reference to the oil and gas sector. One study compared seven Canadian oil companies and found that the two companies most proactive on environmental improvements greatly benefited from higher profits and 
Table 2. Core environmental indicators reported by selected oil companies for 2010 .

\begin{tabular}{|c|c|c|c|c|c|c|}
\hline \multirow[t]{2}{*}{ Company } & \multirow[t]{2}{*}{ Country } & \multicolumn{5}{|c|}{ Core Environmental Indicators } \\
\hline & & Hydrocarbon Spills & $\begin{array}{l}\text { Greenhouse } \\
\text { Emissions }\end{array}$ & Flared Gas & Energy Use & Waste \\
\hline \multicolumn{7}{|c|}{ Oil companies from OECD countries } \\
\hline $\mathrm{BP}$ & UK & REPORTED & REPORTED & REPORTED & REPORTED & REPORTED \\
\hline Shell & UK/Netherl. & REPORTED & REPORTED & REPORTED & REPORTED & REPORTED \\
\hline Chevron & USA & REPORTED & REPORTED & REPORTED & REPORTED & LIMITED \\
\hline Exxon & USA & REPORTED & REPORTED & REPORTED & LIMITED & REPORTED \\
\hline Statoil & Norway & REPORTED & REPORTED & LIMITED & REPORTED & LIMITED \\
\hline Total & France & REPORTED & REPORTED & REPORTED & REPORTED & REPORTED \\
\hline ENI & Italy & REPORTED & REPORTED & REPORTED & REPORTED & REPORTED \\
\hline Repsol & Spain & REPORTED & REPORTED & REPORTED & REPORTED & REPORTED \\
\hline OMV & Austria & REPORTED & REPORTED & REPORTED & REPORTED & REPORTED \\
\hline MOL & Hungary & REPORTED & REPORTED & - & - & REPORTED \\
\hline \multicolumn{7}{|c|}{ Oil companies from non-OECD countries } \\
\hline $\mathrm{CNOOC} \dagger$ & China & LIMITED & - & - & - & - \\
\hline Sinopec & China & - & LIMITED & LIMITED & - & - \\
\hline Lukoil & Russia & - & REPORTED & - & - & REPORTED \\
\hline Gazprom & Russia & - & REPORTED & - & LIMITED & REPORTED \\
\hline ONGC & India & - & REPORTED & REPORTED & REPORTED & - \\
\hline Indian Oil & India & - & LIMITED & - & LIMITED & - \\
\hline Petrobras $\dagger$ & Brazil & REPORTED & REPORTED & - & REPORTED & LIMITED \\
\hline Petronas & Malaysia & LIMITED & REPORTED & LIMITED & LIMITED & - \\
\hline Saudi Aramco & Saudi Arabia & - & - & - & LIMITED & - \\
\hline ADNOC & UAE $\ddagger$ & LIMITED & REPORTED & REPORTED & REPORTED & REPORTED \\
\hline
\end{tabular}

Source: Sustainability or CSR reports for the respective companies, covering data for 2010

$† 2009$ data; $\ddagger$ United Arab Emirates

innovations such as technology patents in the areas of process improvement, sulfur dioxide recovery, waste reduction and disposal, soil restoration, and less polluting fuels (Sharma and Vredenburg 1998). Another study on large multinational oil companies found that there is often a convergence of environmental and business interests, for instance, in terms of reducing carbon dioxide emissions or implementing a zerospill policy for the company (Frynas 2009). In sum, existing business research implies that both companies and the natural environment could greatly benefit from voluntary initiatives such as oil spill prevention.

\section{POTENTIAL OF CSR FOR ADDRESSING OIL SPILLS}

As one indication of CSR, oil companies now provide extensive reporting on their environmental performance, as part of their annual sustainability or CSR reports. As part of this reporting, most large oil companies publish some environmental indicators on an annual basis. Recommended environmental indicators for voluntary self-reporting by oil companies are contained in the universal Global Reporting Initiative (GRI) G3 guidelines published in 2006 (Global Reporting Initiative 2006) and the sector-specific Oil and Gas Industry Guidance on voluntary sustainability reporting (hereafter: Oil Guidance) published in 2010 (IPIECA 2010).

In order to investigate the quality of voluntary environmental self-reporting, this study has analyzed the 2010 sustainability reports by 20 leading oil and gas companies. Sample selection was based on ensuring a wide variance in terms of headquarter location of the organizations in order to reduce a developed country bias. The analysis includes 10 oil companies from OECD countries (including Exxon, Shell, among others) and 10 oil companies from non-OECD countries (including Brazil's Petrobras, and Saudi Aramco, among others).

Table 2 lists 20 oil companies and five key areas for environmental reporting in the oil sector. For oil spills in Table 2, "Reported" means that the company reports both the absolute number of oil spills (normally above 1 barrel) and the volume of oil spills (in barrels, metric tons or another unit of measurement), in line with the recommendations by the 2010 Oil Guidance; "Limited" means that the company only provides part of the information. Table 2 suggests that companies from OECD countries normally report on oil spills (all companies in our samples provide data), but companies from non-OECD countries do not normally provide that data (Brazil's Petrobras is the only exception in our sample).

The lack of an environmental report would not necessarily imply that a company is irresponsible, but regular publication of consistent oil spill and other environmental data may help to compare the performance of companies and to encourage them toward improvements (Frynas 2009:87). The incidence of oil spills is not entirely comparable year-by-year because it can be affected by levels of production and by natural 
Table 3. Number of self-reported oil spills by selected companies, 2001-2010.

\begin{tabular}{lcccccccccc}
\hline \hline & 2001 & 2002 & 2003 & 2004 & 2005 & 2006 & 2007 & 2008 & 2009 & 2010 \\
\hline $\mathrm{BP} \dagger$ & 810 & 761 & 635 & 578 & 541 & 417 & 213 & 170 & 122 & 142 \\
Chevron $\dagger$ & 1428 & 1502 & 1145 & 986 & 846 & 803 & 826 & 760 & 798 & 639 \\
Exxon $\dagger$ & $\mathrm{n} / \mathrm{a}$ & $\mathrm{n} / \mathrm{a}$ & 466 & 475 & 370 & 295 & 253 & 211 & 242 & 210 \\
Shell $\ddagger$ & $\mathrm{n} / \mathrm{a}$ & 912 & 780 & 812 & 671 & 588 & 589 & 390 & 370 & 305 \\
\hline
\end{tabular}

$\dagger$ spills above 1 barrel

† spills above 100 kilograms

disasters (e.g., hurricanes in 2005), and the volume of oil spills in a given year can be affected by a particularly large oil spill. Nonetheless, a comparison of oil spill data for 2001-2010 provided by companies in their CSR reports suggests that some companies are progressively reducing the number of even the smallest oil spills (see Table 3). Unfortunately, the selfreported data does not allow a comparison of spill volumes between the companies. Furthermore, available statistical data for 2002-2010 by the International Association of Oil and Gas Producers (which is also based on self-reported data by member companies) does not corroborate a general downward trend reported by some individual company reports (see Table 4).

The most impressive evidence on oil spill prevention is provided by a historical comparison of major oil spills from oil tankers (Burgherr 2007). Since the 1970s, the number of major oil spills (above 700 metric tons) caused by oil tankers and other vessels has dramatically decreased from an average 25.3 spills per year in the period 1970-1979 to 3.3 spills per year in the period 2000-2009. During the 1970s, almost 30 major oil spills per year was not unusual. During the period 2000-2009, the highest annual number of major oil spills was five in 2004 and 2006. The volume of oil spills has also dramatically decreased over the last three decades, except for the year 2002 when the Greek-owned oil tanker "Prestige" sank off the coast of Spain (see Figures 1 and 2).

A reduction in oil spills raises the question as to what extent CSR contributed to better oil spill prevention. Voluntary regulation already started in 1969 when oil companies established an industry-wide voluntary agreement called the Tanker Owners' Voluntary Agreement concerning Liability for Oil Pollution (referred to as TOVALOP) and in 1974, the Offshore Pollution Liability Agreement (referred to as OPOL) was set up to meet claims for marine pollution damage and environmental cleanup costs. Under the terms of these agreements, oil companies voluntarily accepted strict liability for pollution damage and the cost of remedial measures (International Oil Pollution Compensation Funds 2004). Another early example of voluntary regulation for oil spill prevention was the Oil Companies International Marine Forum (OCIMF), a voluntary association of oil companies founded in 1970 dedicated to the mission of being "the foremost authority on the safe and environmentally responsible operation of oil tankers, terminals and offshore support vessels, promoting continuous improvement in standards of design and operation" (Oil Companies International Marine Forum 2011). As of 2011, OCIMF had 86 members, including large multinational companies like Shell and Petrobras (Oil Companies International Marine Forum 2011).

Fig. 1. Number of marine oil spills worldwide over 700 metric tonnes from 1970-2010.

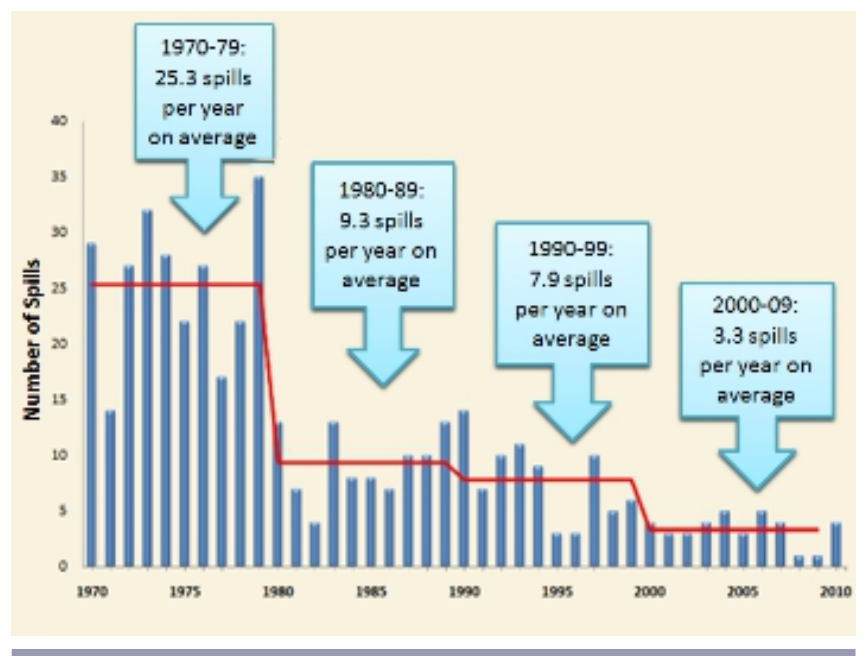

A reduction in marine oil spills should be at least partly attributed to improved condition of oil tankers and other ships, which in turn may be at least partly attributed to voluntary initiatives. OCIMF's key voluntary initiative was the launching of the Ship Inspection Report Programme (SIRE) in 1993, giving rise to a sophisticated vetting system for oil tankers with the ultimate purpose of improving the condition of ships. SIRE created a vast database of up-to-date information about oil tankers and other vessels. OCIMF member companies carry out ship inspections according to a standard protocol, and the inspection results are reported to the SIRE database. As of October 2011, the database held over 22,500 reports on over 8000 vessels, with an inspection conducted in the previous 12 months. The inspection results 
Table 4. Quantity of oil spilled onshore and offshore per unit of hydrocarbon production (tonnes per million tonnes), 2002-2010.

\begin{tabular}{lccccccccc}
\hline \hline & 2002 & 2003 & 2004 & 2005 & 2006 & 2007 & 2008 & 2009 & 2010 \\
\hline Onshore & 13.1 & 7.5 & 6.0 & 7.9 & 17.3 & 10.9 & 18.5 & 47.0 & 7.1 \\
Offshore & 0.3 & 1.8 & 0.5 & 0.6 & 0.4 & 4.0 & 3.0 & 1.6 & 0.7 \\
Total & 5.9 & 4.5 & 3.7 & 4.3 & 7.6 & 6.9 & 8.7 & 18.8 & 4.5 \\
\hline
\end{tabular}

Source: Annual reports (2003-2011) of the International Association of Oil and Gas Producers. Environmental Performance in the E\&P Industry. London, United Kingdom.

can be viewed by OCIMF member companies, port authorities, specific government bodies and others, creating strong incentives for vessel owners to eliminate all vessel defects.

While it is difficult to differentiate between the impact of voluntary and mandatory regulation, recent statistical analysis suggests that SIRE inspections decrease the risk of ship accidents, and the effect of inspections increases with ship age (Bijwaard and Knapp 2009). Another recent study on shipping and marine safety concluded that "tankers, dry bulk carriers, and general cargo vessels have improved more, in comparison with passenger and container vessels, perhaps due to the impact of industry vetting inspections for tankers and dry bulk carrier" (Knapp and van de Velden 2011:599). Given that voluntary ship inspections help to reduce the number of ship accidents and oil spills, recent statistical analysis suggests that such inspections lead to substantial long-term cost savings for oil companies (Knapp et al. 2011), which is in line with our expectations that voluntary initiatives can benefit both the natural environment and oil companies.

The aftermath of the 1989 Exxon Valdez spill provides another example of the potential of voluntary regulation for oil spill prevention. The reduction in oil spills in U.S. waters in the period 1990-1995 has been attributed to a number of voluntary initiatives, since this reduction had already occurred before the 1990 Oil Pollution Act was fully operational in 1996. These voluntary initiatives included an increase in company awareness of liability, improved audit and inspection of ships, increased efforts by classification societies to ensure vessels meet requirements, voluntary replacement of old vessels with double-hull vessels, improved staff training, and vessel routing changes, although it is not possible to directly link one specific factor to oil spill reduction (U.S...1996, Kim 2002).

While mandatory regulation normally focuses on compliance with basic minimum requirements, one key advantage of CSR is that it can help develop new and better environmental practices, for instance, the use of better materials (e.g., replacing steel tubes with chrome tubes) or better oil spill cleanup techniques (e.g., burning oil in broken ice) (Frynas 2009, Sørstrøm et al. 2010). Indeed, the business literature suggests that CSR can lead to a multitude of environmental innovations (Lanjouw and Mody 1996, Sharma and Vredenburg 1998) because it can force companies to question existing assumptions and to seek new strategies to grow and develop their business (Kanter 1999, Porter and Kramer 2006). This points to the general strength of voluntary initiatives in terms of using private sector creativity to decide on the process of how to achieve desired environmental improvements.

Better environmental practices and innovations have become of greater importance for oil spill prevention, since oil operations are expanding into technologically more challenging environments, including the Arctic and ultra deepwater areas. Furthermore, many developing nations may not have the capacity to effectively regulate a technically sophisticated industry (related to their lack of institutional capacity and the lack of government funding for effectively enforcing high environmental standards) and voluntary regulation may occasionally offer a better hope of addressing environmental issues. Indeed, the lack of adequate mandatory regulation in developing economies may be the main argument for encouraging voluntary environmental regulation among companies. Examples of voluntary environmental measures, even when there was little government pressure to do so, include the replacement of old pipelines in Nigeria and the introduction of the European standards of environmental selfreporting in Egypt (Frynas 2009).

\section{LIMITATIONS OF CSR VERSUS MANDATORY REGULATION}

The information presented thus far relied heavily on selfreported oil spill data. However, voluntary environmental reporting raises questions about the reliability of self-reported company data. For instance, BP sustainability report 2006 reported 417 oil spills in 2006, while BP sustainability report 2010 reported 300 oil spills in the same year 2006; the 2010 report also failed to include the volume of oil spilled in the 2010 Deepwater Horizon accident in its reported figure for 2010 as the spill volume was still undetermined. China's largest oil company Sinopec stated in its 2010 sustainability report that "there were no accidents that caused major pollution to the environment" and Russia's largest oil company Lukoil made similar claims about oil spills in 2010, claims that are difficult to believe for a company of Sinopec's or Lukoil's size. Many large oil companies use external assurance organizations to verify CSR reports, but the self-reported environmental indicators are normally not questioned.

Voluntary environmental reporting raises questions about comparability. Over the last decade, efforts have been made 
Fig. 2. Quantity of marine oil spills (metric tonnes) worldwide from 1970-2010.

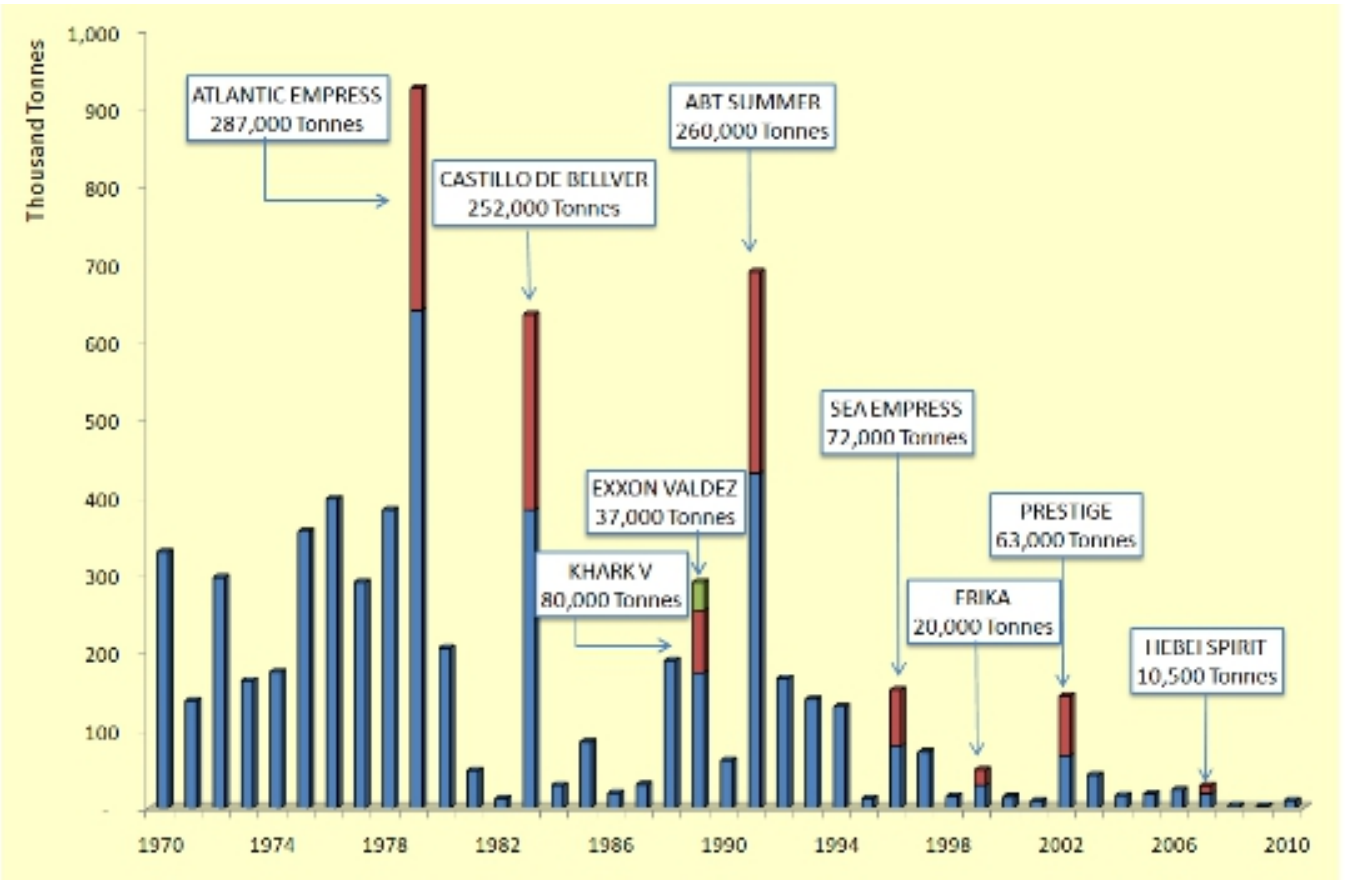

to standardize voluntary environmental reporting through the 2005 and 2010 Oil Guidance and subsequently improved editions of GRI guidelines. However, it is still impossible to compare the most basic data even among those oil companies that are most active in CSR initiatives. For instance, BP reports volume of oil spills in million liters, Shell in thousand metric tons, Exxon in thousand barrels and Statoil in cubic meters. Conversion from one unit of measurement to another is difficult because of the different chemical properties of different varieties of crude oil.

Most large companies report the total spill number and volume, while a number of others such as Shell use different categories; for example, Shell distinguishes between operational spills, sabotage spills, and hurricane spills and does not provide a single composite figure. Some companies count different types of oil spills differently, for instance, as part of its reported total figure for oil spills, Chevron counts oil spills to land above one barrel only, but Chevron counts all spills to water, including those that are smaller than one barrel. As a result, the number of Chevron spills would appear to be a lot higher than the number of spills caused by Shell and other companies, but it only means that Chevron has been more conscientious in terms of providing data.

In sum, despite the use of the same GRI or Oil Guidance recommendations, it is impossible to compare oil spill performance between companies. In other words, voluntary regulation currently fails to provide even the most basic level of transparency on oil spill performance.

More seriously, leading business thinkers writing about environmental management themselves suggest that mandatory environmental regulation is necessary for companies to be pushed into action for several key reasons, including to educate the majority of companies about the opportunities for better resource use and technological improvements, to create a demand for environmental improvements until the market is capable of perceiving and measuring the benefits of environmental improvements, and to level the playing field in order to ensure that a company cannot gain a competitive advantage by avoiding environmental improvements (Van der Linde 1993, Porter and Van Der Linde 1995). In other words, the industry cannot be left to decide the desired environmental outcomes.

Indeed, previous empirical studies demonstrate that voluntary initiatives are often motivated by existing and anticipated pressures of mandatory regulations (Nakamura et al. 2001, Khanna and Anton 2002, Uchida and Ferraro 2007). With regard to oil spills specifically, companies are said to be aware that major oil spills often lead to public calls for greater regulation and "voluntary" regulation can be a means to avert mandatory regulation, since companies normally prefer voluntary self-regulation (Frynas 2009:92-94). For example, the Exxon Valdez oil spill in 1989 led to the creation of the 
Table 5. Selected marine oil spills and development of mandatory regulations relevant to oil tankers, 1967-2005.

\begin{tabular}{|c|c|c|c|c|c|}
\hline$\overline{\text { Year }}$ & Ship name & Location & Spill size (tons) & Economic cost & Resulting regulation \\
\hline 1967 & Torrey Canyon & Scilly Isles, UK & 119,000 & $\mathrm{n} / \mathrm{a}$ & $\begin{array}{l}1969 \text { CLC Convention } \\
1971 \text { FUND Convention }\end{array}$ \\
\hline 1978 & Amoco Cadiz & Off the coast of France & 223,000 & US\$ 282 million & $\begin{array}{l}1981 \text { and } 1983 \text { SOLAS Amendments } \\
1982 \text { Paris MoU on Port State Control }\end{array}$ \\
\hline 1989 & Exxon Valdez & Prince William Sound, USA & 37,000 & US\$ 9.5 billion & $\begin{array}{l}1990 \text { Oil Pollution Act in the US } \\
1992 \text { MARPOL Amendment }\end{array}$ \\
\hline 1999 & Erika & Off the coast of France & 20,000 & US\$ 180 million & 2001 MARPOL Amendment \\
\hline 2002 & Prestige & Off the coast of Spain & 63,000 & 778 million Euro & $\begin{array}{l}2003 \text { EU Regulation } 1726 / 2003 \\
2003 \text { MARPOL Amendment } \\
2005 \text { EU Third Maritime Safety Package }\end{array}$ \\
\hline
\end{tabular}

Abbreviations: CLC = International Convention on Civil Liability for Oil Pollution Damage; FUND = International Convention on the Establishment of an International Fund for Compensation for Oil Pollution Damage; MARPOL = International Convention for the Prevention of Pollution From Ships (MARPOL is abbreviation for Marine Pollution); $\mathrm{MoU}=$ Memorandum of Understanding; SOLAS = International Convention for the Safety of Life at Sea (SOLAS is abbreviation for Safety of Life at Sea); Sources: Adapted from Bijwaard and Knapp (2009) and Knapp and Franses (2009).

Oil Pollution Act in the United States in 1990 while the Erika and Prestige oil spills (1999 and 2002) led to the revision of regulations in the European Union (EU), the so-called EU Third Maritime Safety Package (Bijwaard and Knapp 2009). Table 5 summarizes the principal marine oil spills that directly led to the development of mandatory regulations relevant to oil tankers.

Similarly, it has been shown that voluntary initiatives such as TOVALOP and OPOL (mentioned earlier) were designed to preempt national regulation (Frynas 2009:93-94). OCIMF themselves admit that its foundation was "initially the oil industry's response to increasing public awareness of marine pollution, particularly by oil, after the 'Torrey Canyon' incident [oil spill in 1967]", while SIRE was a response to the Exxon Valdez oil spill (Oil Companies International Marine Forum 2011). Other voluntary initiatives responsible for the earlier mentioned reduction in oil spills in U.S. waters in the period 1990-1995 were also a response to the Exxon Valdez spill and were based on the expectation of greater future mandatory regulation by federal and state authorities. As this author has previously argued, "many 'voluntary' environmental initiatives in the oil and gas sector may not have happened without government pressures on the oil companies" (Frynas 2009:96).

In other words, CSR may serve to stave off mandatory regulation. Previous research suggests that oil companies can strategically influence the political process to their commercial advantage (Frynas 1998, Frynas et al. 2006). While lobbying by firms can occasionally help achieve more stringent environmental regulations (McWilliams et al. 2002), conversely CSR can occasionally benefit firms by influencing regulators to be more lenient on industry-related regulations, for instance, TOVALOP and OPOL have helped with the establishment of the principle of the maximum amount of compensation for oil spills irrespective of damage (Frynas 2009:94). In addition to specific lobbying and negotiation efforts, reporting on CSR in general can help firms to influence public opinion and decision makers by portraying firms as responsible citizens that care about people and the environment as much as about profits, while the same firms may lobby for socially undesirable legislation such as labor market flexibilization (Utting 2007) or continue to be secretive about some parts of their operations such as anticorruption programs (Transparency International 2008:24). Henriques (2007:150) commented that it is ironic that CSR or sustainability reports "were originally conceived as mechanisms for companies to demonstrate that they were being influenced by their stakeholders, rather than vehicles for the opposite".

As a final fundamental limitation of CSR and related to the previous argument, multinational oil companies may occasionally face a conflict of interest between commercial interests and environmental concerns. Oil and gas deposits are often located in developing countries near or inside ecologically vulnerable areas (Austin and Sauer 2002). Commercial development of oil reserves carries a high risk of significant oil spill damage in these areas, while the lack of commercial development of these areas would mean less profit for oil companies. Not surprisingly, even corporate leaders in "sustainability" may decide that commercial interests are more important than oil spill prevention. Examples include the decision of Petrobras to drill for oil in the Yasuni National Park in Ecuador (Chen 2007) and the construction of the BPStatoil Baku-Ceyhan pipeline through the catchment area for mineral springs in the Asian country of Georgia (Centre for Civic Initiatives et al. 2005). All three companies (Petrobras, BP and Statoil) are considered global sustainability leaders in the oil and gas sector, yet all three companies failed to observe best environmental practices in these projects and disregarded concerns raised by environmentalists and the governments of Ecuador and Georgia about the dangers of oil spills. Indeed, a study by Pegg (2006) previously argued that, given the firms' inherent commercial self-interests, there are fewer distinctions 
Table 6. Quantity of oil spilled onshore and offshore per unit of hydrocarbon production (tonnes per million tonnes), by region (2010 data).

\begin{tabular}{|c|c|c|c|c|c|c|c|c|}
\hline & Africa & $\begin{array}{l}\text { Asia/ } \\
\text { Australasia }\end{array}$ & Europe & $\begin{array}{l}\text { Former Soviet } \\
\text { Union }\end{array}$ & Middle East & North America & South America & Total \\
\hline Onshore & 53.11 & 4.86 & 1.39 & 0.48 & 0.79 & 3.40 & 12.86 & 7.08 \\
\hline Offshore & 1.63 & 0.48 & 0.57 & 0.72 & 0.09 & 0.10 & 0.15 & 0.69 \\
\hline Unspecified & 37.76 & 0.31 & 0.74 & no data & no data & 2.13 & no data & 19.61 \\
\hline Total & 17.27 & 1.57 & 0.70 & 0.58 & 0.62 & 2.67 & 4.04 & 4.51 \\
\hline
\end{tabular}

Source: International Association of Oil and Gas Producers. 2011.

in terms of CSR between Western sustainability leaders and Asian oil companies than many observers assume.

Government regulation also has limitations. For instance, one study demonstrated a number of weaknesses of the International Oil Pollution Compensation Funds (IOPC Funds) including that compensation claims may not necessarily be paid quickly or in full (Wren 2000), which may potentially reduce financial incentives for oil spill prevention. Another study compared public disclosure of oil spill data from offshore installations in four countries (United States, Australia, Canada, and the UK), and found that there was significant variation in the available spill data statistics and that no country provided full disclosure of spill data; the lack of reliable spill data disclosure may negatively affect postspill adaptation as the scale of environmental effects is more difficult to assess, insufficient information is available to assess the accuracy of predictions made in the environmental assessment process, and it may not be possible to compare regional differences in spill rates (Fraser et al. 2008).

Possibly the main limitation of government legislation is that many developing countries may not have the capacity to effectively regulate a technically sophisticated industry such as the oil and gas sector and formal regulatory approaches to environmental issues have often failed in developing countries. For instance, the legal framework for the control and management of water pollution in Nigeria has been found to be inadequate in a number of studies, pointing to the lack of technical/institutional capacity among Nigerian government agencies for enforcing high environmental standards (Frynas 2000, Adedeji and Ako 2009). Statistical data by the International Association of Oil and Gas Producers demonstrates a wide gap in the frequency of oil spills between developed and developing countries. In 2010, the volume of oil spills per million tonnes hydrocarbon production (i.e., spill volume adjusted for oil production volume) was 17.27 tonnes in Africa, compared with 0.7 tonnes in Europe (see Table 6). Onshore oil spills (which are largely subject to national and local legislation only) present a much larger environmental hazard than offshore oil spills (which benefit from improvements as a result of international legislation such as the MARPOL convention) (see Table 4) and this is most evident in developing countries: 53.11 tonnes in African onshore oil spills versus only 1.63 tonnes in African offshore oil spills (see Table 6). In turn, these statistics are related to the fact that the same companies apply very different environmental standards in different legal jurisdictions. For instance, while Royal Dutch Shell claims to have in place some exemplary environmental practices in developed countries (Rookmin and Herremans 2008, Sluyterman 2010), recent reports by the UN Environment Programme and Amnesty International found that Shell still does not apply some basic international standards with regard to oil spills in Nigeria where Shell has caused thousands of oil spills since the start of oil operations in the late 1950s (Amnesty International 2011, United Nations Environment Program 2011).

Nonetheless, the main strength of mandatory regulation is that it can create a regulatory system that applies to every company within a given jurisdiction, while voluntary CSR initiatives normally only apply to companies that voluntarily choose to be part of a specific initiative.

One notable example of the advantages of government regulation is the phasing out of single-hull oil tankers and the introduction of double-hull tankers. For instance, all shipping companies in U.S. waters have to abide by the 1990 Oil Pollution Act; notably, all companies are obliged to convert their fleets to double-hull tankers for most tanker trades by 2015, while amendments to the MARPOL convention also mandate the phasing out of single-hull tankers on a global scale. Statistical studies demonstrate that double-hull tankers have a lower incidence rate than single-hull tankers and that double-hull design significantly reduces the size of oil spills on average (Bijwaard and Knapp 2009, Yip et al. 2011) and that MARPOL amendments related to the phaseout of singlehull tankers decreased the number of pollution incidents and, to some extent, the amount of pollution (Knapp and Franses 2009). Alongside international conventions, national legislation can make a critical contribution toward oil spill prevention. Most notably, statistical studies demonstrate that there was a reduction in the number and volume of oil spills in U.S. waters as a result of the 1990 Oil Pollution Act, specifically as a result of increased legal liability for oil spills and the introduction of double hulls (Ketkar 2002, Homan and Steiner 2008). Voluntary initiatives would unlikely succeed in forcing every single ship owner to convert to double-hull 
tankers because there are wide differences in terms of approaches to safety across the industry.

\section{CONCLUSION}

Evidence presented here demonstrates that oil spill prevention has generally improved over recent decades, but it is less clear to what extent CSR played a part in these improvements. The existing literature does not as yet provide unambiguous evidence of causality between CSR and oil spill reduction. Causality between mandatory government regulation and oil spill reduction is much more clearly established.

CSR has potentially some benefits vis-à-vis mandatory regulation. Environmental challenges benefit from the specific expertise that companies possess, as these specific technical and managerial skills can help bring about environmental improvements. Voluntary initiatives can be implemented faster than government policy, and they can greatly exceed the requirements of legal compliance by leading to innovations in the use of materials, technologies, or operating procedures. Most crucially, voluntary environmental initiatives can lead to win-win outcomes: the environmental impact of companies is reduced, while companies benefit from lower operating costs, better equipment, and innovation. In this context, one can distinguish between outcome-setting CSR (e.g., voluntary introduction of double-hull ships or setting of a zero-spill policy as a desired outcome) and process-setting CSR (development of better oil spill cleanup techniques or establishment of the SIRE database as processes for achieving desired outcomes). The evidence in this study points to the general strengths of process-setting CSR and weaknesses of outcome-setting CSR.

However, given the various benefits of voluntary selfregulation for companies themselves, it is perhaps surprising that there are wide differences in terms of oil spill prevention and self-reporting of oil spills across the industry. Some companies may be more active on environmental improvements than others because companies react differently to the economic opportunities for voluntary action; for instance, companies may be slow in recognizing the economic opportunities associated with CSR, they may be risk-averse, they may find it difficult to reengineer their internal management systems or they may sacrifice future economic opportunities at the expense of short-term financial considerations.

Conversely, mandatory regulation can help to reduce uncertainties about the future, improve the economic incentives for companies to act responsibly, and ensure a level playing field for everyone. Furthermore, mandatory regulation can create a regulatory system that applies to every single company within a given jurisdiction, not just "volunteer" companies. Indeed, our research suggests that various voluntary CSR initiatives may not have come into existence without pressures for mandatory government regulation. This further points to the importance of the outcome-setting role of government intervention.

However, it is obvious that mandatory government regulation is not a panacea. Appeals by nongovernment organizations for more mandatory regulation seem to ignore the many historical failures of formal regulatory approaches to social and environmental issues, especially in developing countries. On one hand, evidence suggests that both CSR initiatives (e.g., introduction of SIRE) and mandatory government regulation (e.g., universal adoption of double-hull tankers) have benefited oil spill prevention. On the other hand, evidence suggests that both CSR and government regulation have failed to instill global best practices in terms of oil spill prevention in parts of the developing world, especially with regard to onshore oil spills.

It follows that we need to learn more about the optimal balance of voluntary and mandatory, national and international, prescriptive and enabling regulation. Debates on CSR must therefore move beyond unproductive calls for or against CSR or government regulation toward studying new hybrid forms of regulation, supported by capacity building of public agencies in developing countries. Such hybrid regulation can include public voluntary programs (e.g., environmental agency inviting firms to voluntarily apply certain environmental standards such as previous programs to reduce greenhouse gas emissions) and negotiated agreements between firms and regulators (e.g., the government setting abatement targets and the environmental agency negotiating with firms on the best methods and timetable for achieving abatement targets) (Carraro and Lévêque 1999, Khanna 2001).

Some hybrid regulations on environmental practices already exist but the evidence on their effectiveness is mixed even when the same public agency is involved; for instance, a number of public voluntary programs initiated by the U.S. Environmental Protection Agency (USEPA) have been considered a significant success, while a number of negotiated agreements involving USEPA had little success (Khanna 2001). The author believes that an optimal hybrid regulation would combine outcome-setting by a government within its jurisdiction (setting appropriate environmental outcomes and compelling firms to join an initiative) with process-setting CSR (using the creativity of the private sector to find solutions for achieving desired environmental outcomes). One possible explanation why some hybrid regulations in the oil and gas sector had previously limited success is that the government was not ambitious, focused or effective enough in terms of outcome-setting and/or was too closely involved in terms of process-setting; for instance, studies demonstrate that the crucial limitation of the Extractive Industries Transparency Initiative was the misplaced focus on government revenues instead of the more important government expenditures 
(Frynas 2009, Kolstad and Wiig 2009). Future research needs to investigate the factors that are necessary for effective hybrid regulations.

Papers in this special issue demonstrate that local communities are highly dependent on external public and private bodies to adapt to oil spills. It is high time that public and private bodies work more closely together not just to adapt to environmental disasters, but to prevent such disasters in the first instance.

Responses to this article can be read online at: http://www.ecologyandsociety.org/issues/responses. php/5073

\section{Acknowledgments:}

The author is very grateful to the reviewers and the editor for comments on earlier drafts, which have helped to improve the quality of the paper.

\section{LITERATURE CITED}

Adedeji, A. A., and R. T. Ako. 2009. Towards achieving the United Nations' Millennium Development Goals: the imperative of reforming water pollution control and waste management laws in Nigeria. Desalination 248:642-649.

Amnesty International. 2011. The true 'tragedy': delays and failures in tackling oil spills in the Niger Delta. Amnesty International, London, United Kingdom.

Austin, D., and A. Sauer. 2002. Changing oil: emerging environmental risks and shareholder value in the oil and gas industry. World Resources Institute, Washington, D.C., USA.

Bijwaard, G. E., and S. Knapp. 2009. Analysis of ship life cycles - the impact of economic cycles and ship inspections. Marine Policy 33(2):350-369. http://dx.doi.org/10.1016/j. marpol.2008.08.003

Blowfield, M. and J.G. Frynas. 2005. Setting new agendas critical perspectives on corporate social responsibility in the developing world. International Affairs 81(3):499-513.

Blowfield, M., and A. Murray. 2008. Corporate responsibility - a critical introduction. Oxford University Press, Oxford, UK.

Burgherr, P. 2007. In-depth analysis of accidental oil spills from tankers in the context of global spill trends from all sources. Journal of Hazardous Materials 140(1-2):245-256. http://dx.doi.org/10.1016/j.jhazmat.2006.07.030

Carraro, C., and F. Lévêque, editors. 1999. Voluntary approaches in environmental policy. Kluwer, Dordrecht, The Netherlands.
Carroll, A. B. 1999. Corporate social responsibility - evolution of a definitional construct. Business and Society 38:268-295. http://dx.doi.org/10.1177/000765039903800303

Centre for Civic Initiatives, Committee for the Protection of Oil Workers Rights, CEE Bankwatch Network, Green Alternative, Kurdish Human Rights Project, PLATFORM, and Urgewald. 2005. Baku-Tbilisi-Ceyhan Oil Pipeline: human rights, social and environmental impacts (Georgia Section) - final report of fact finding mission, September, 16-18, 2005. Centre for Civic Initiatives, Committee for the Protection of Oil Workers Rights, CEE Bankwatch Network, Green Alternative, Kurdish Human Rights Project, PLATFORM, and Urgewald, Baku, Azerbaijan.

Chen, M. E. 2007. National oil companies and corporate citizenship: a survey of transnational policy and practice. The James A. Baker III Institute for Public Policy, Rice University, Houston, Texas, USA.

Clark, R. B., editor. 1982. The long-term effects of oil pollution on marine populations, communities and ecosystems. Royal Society, London, UK. http://dx.doi.org/10.1098/rstb.1982.0037

Estrada, J., K. Tangen, and H. O. Bergesen. 1997. Environmental challenges confronting the oil industry. Wiley, New York, USA.

Fraser, G. S., J. Ellis, and L. Hussain. 2008. An international comparison of governmental disclosure of hydrocarbon spills from offshore oil and gas installations. Marine Pollution Bulletin 56:9-13. http://dx.doi.org/10.1016/j.marpolbul.2007.09.032

Freeman, I., and A. Hasnaoui. 2011. The meaning of corporate social responsibility: the vision of four nations. Journal of Business Ethics 100(3):419-443. http://dx.doi.org/10.1007/ s10551-010-0688-6

Friedman, M. 1962. Capitalism and freedom. University of Chicago Press, Chicago, Illinois, USA.

Frynas, J. G. 1998. Political instability and business: focus on Shell in Nigeria. Third World Quarterly 19(3):457-479. http:// dx.doi.org/10.1080/01436599814343

Frynas, J. G. 2000. Oil in Nigeria: conflict and litigation between oil companies and village communities. LIT Verlag and Transaction Publishers, Hamburg, Germany and New Brunswick, New Jersey, USA.

Frynas, J. G. 2009. Beyond corporate social responsibility oil multinationals and social challenges. Cambridge University Press, Cambridge, UK. http://dx.doi.org/10.1017/ CBO9780511581540

Frynas, J. G. 2010. Oil industry's increasing focus on CSR. Petroleum Economist February.

Frynas, J. G., K. Mellahi, and G. Pigman. 2006. First mover advantages in international business and firm-specific 
political resources. Strategic Management Journal 27:321-345. http://dx.doi.org/10.1002/smj.519

Gillies, A. 2010. Reputational concerns and the emergence of oil sector transparency as an international norm. International Studies Quarterly 54(1):103-126. http://dx.doi.org/10.1111/ j.1468-2478.2009.00579.x

Global Reporting Initiative (GRI). 2006. G3 Guidelines. [online] URL: http://www.globalreporting.org/reporting/ latest-guidelines/g3-guidelines/Pages/default.aspx

Henderson, D. 2001. Misguided virtue: false notions of corporate social responsibility. Institute of Economic Affairs, London, UK.

Henriques, A. 2007. Corporate truth - the limits to transparency. Earthscan, London, United Kingdom.

Homan, A. C., and T. Steiner. 2008. OPA 90's impact at reducing oil spills. Marine Policy 32:711-718. http://dx.doi. org/10.1016/j.marpol.2007.12.004

International Association of Oil and Gas Producers. 2003. Environmental performance in the E\&P industry. International Association of Oil and Gas Producers, London, United Kingdom.

International Association of Oil and Gas Producers. 2004. Environmental performance in the E\&P industry. International Association of Oil and Gas Producers, London, United Kingdom.

International Association of Oil and Gas Producers. 2005. Environmental performance in the E\&P industry. International Association of Oil and Gas Producers, London, United Kingdom.

International Association of Oil and Gas Producers. 2006. Environmental performance in the E\&P industry. International Association of Oil and Gas Producers, London, United Kingdom.

International Association of Oil and Gas Producers. 2007. Environmental performance in the E\&P industry. International Association of Oil and Gas Producers, London, United Kingdom.

International Association of Oil and Gas Producers. 2008. Environmental performance in the E\&P industry. International Association of Oil and Gas Producers, London, United Kingdom.

International Association of Oil and Gas Producers. 2009. Environmental performance in the E\&P industry. International Association of Oil and Gas Producers, London, United Kingdom.

International Association of Oil and Gas Producers. 2010. Environmental performance in the E\&P industry. International Association of Oil and Gas Producers, London, United Kingdom.
International Association of Oil and Gas Producers. 2011. Environmental performance in the E\&P industry. International Association of Oil and Gas Producers, London, United Kingdom.

International Oil Pollution Compensation Funds, editor. 2004. The lOPC Funds' 25 years of compensating victims of oil pollution incidents. International Oil Pollution Compensation Funds, London, UK.

IPIECA. 2010. Oil and gas industry guidance on voluntary sustainability reporting. [online] URL: http://www.ipieca. org/sites/default/files/publications/Reporting Guidance-28 Sept 2011. pdf

Kanter, R. M. 1999. From spare change to real change: the social sector as beta site for business innovation. Harvard Business Review 77(3):122-132.

Ketkar, K. W. 2002. The Oil Pollution Act of 1990: a decade later. Spill Science \& Technology Bulletin 7(1-2):45-52. http:// dx.doi.org/10.1016/S1353-2561(02)00052-X

Khanna, M. 2001. Non-mandatory approaches to environmental protection. Journal of Economic Surveys 15 (3):291-324. http://dx.doi.org/10.1111/1467-6419.00141

Khanna, M., and W. R. Q. Anton. 2002. Corporate environmental management: regulatory and market-based pressures. Land Economics 78(4):539-558.

Kim, I. 2002. Ten years after the enactment of the Oil Pollution Act of 1990: a success or a failure. Marine Policy 26:197-207. http://dx.doi.org/10.1016/S0308-597X(02)00002-7

King, A., and M. Lenox. 2002. Exploring the locus of profitable pollution reduction. Management Science 48:289299. http://dx.doi.org/10.1287/mnsc.48.2.289.258

Knapp, S., G. E. Bijwaard, and C. Heij. 2011. Estimated incident cost savings in shipping due to inspections. Accident Analysis and Prevention 43:1532-1539. http://dx.doi. org/10.1016/j.aap.2011.03.005

Knapp, S., and P. H. Franses. 2009. Does ratification matter and do major conventions improve safety and decrease pollution in shipping? Marine Policy 33:826-846. http://dx. doi.org/10.1016/j.marpol.2009.03.005

Knapp, S., and M. van de Velden. 2011. Global ship risk profiles: safety and the marine environment. Transportation Research Part D 16(8):595-603. http://dx.doi.org/10.1016/j. trd.2011.08.001

Kolstad, I., and A. Wiig. 2009. Is transparency the key to reducing corruption in resource-rich countries? World Development 37(3):521-532. http://dx.doi.org/10.1016/j. worlddev.2008.07.002 
KPMG International. 2011. KPMG International survey of corporate responsibility reporting 2011. [online] URL: http:// www.kpmg.com/PT/pt/IssuesAndInsights/Documents/corporateresponsibility2011.pdf

Lanjouw, J. O., and A. Mody. 1996. Innovation and the international diffusion of environmentally responsive technology. Research Policy 25:549-571. http://dx.doi. org/10.1016/0048-7333(95)00853-5

Lockett, A., J. Moon, and W. Wisser. 2006. Corporate social responsibility in management research: focus, nature, salience and sources of influence. Journal of Management Studies 43 (1):115-136. http://dx.doi.org/10.1111/j.1467-6486.2006.00585. $\underline{\mathrm{X}}$

Matten, D., and A. Crane. 2005. Corporate citizenship: toward an extended theoretical conceptualization. Academy of Management Review 30(1):166-179. http://dx.doi.org/10.5465/ AMR.2005.15281448

Matten, D., and J. Moon. 2008. "Implicit" and "explicit" CSR: a conceptual framework for a comparative understanding of corporate social responsibility. Academy of Management Review 33(2):404-424. http://dx.doi.org/10.5465/

AMR.2008.31193458

McWilliams, A., D. D. Van Fleet, and K.D. Cory. 2002. Raising rivals' costs through political strategy: an extension of resource-based theory. Journal of Management Studies 39 (5):707-723. http://dx.doi.org/10.1111/1467-6486.00308

Miles, M., and J. Covin. 2000. Environmental marketing: a source of reputational, competitive, and financial advantage. Journal of Business Ethics 23:299-311. http://dx.doi. org/10.1023/A:1006214509281

Molina-Azorín, J. F., J. J. Tarí, E. Claver-Cortés and M. D. López-Gamero. 2009. Quality management, environmental management and firm performance: a review of empirical studies and issues of integration. International Journal of Management Reviews 11(2):197-222. http://dx.doi.org/10.1111/ j.1468-2370.2008.00238.x

Nakamura, M., T. Takahashi, and I. Vertinsky. 2001. Why Japanese firms choose to certify: a study of managerial responses to environmental issues. Journal of Environmental Economics and Management 42(1):23-52. http://dx.doi. org/10.1006/jeem.2000.1148

Oil Companies International Marine Forum (OCIMF). 2011. Website of Oil Companies International Marine Forum. [online] URL: fhttp://www.ocimf.com/ (accessed 17 October 2011).

Ottaway, M. 2001. Reluctant missionaries. Foreign Policy July/August:44-54. http://dx.doi.org/10.2307/3183326
Pegg, S. 2006. World leaders and bottom feeders: divergent strategies toward social responsibility and resource extraction. Pages 249-269 in Christopher May, editor. Global corporate power. Lynne Rienner, Boulder, Colorado, USA.

Porter, M. E., and M. R. Kramer. 2006. Strategy \& society the link between competitive advantage and corporate social responsibility. Harvard Business Review 84(12):78-92.

Porter, M. E., and C. Van Der Linde. 1995. Green and competitive: ending the stalemate. Harvard Business Review 73(5):120-134.

Rookmin, M., and I. M. Herremans. 2008. Shell Canada: over a decade of sustainable development reporting experience. Corporate governance: the International Journal of Effective Board Performance 8(3):235-247.

Runhaar, H. and H. Lafferty. 2009. Governing corporate social responsibility: an assessment of the contribution of the UN Global Compact to CSR strategies in the telecommunications industry. Journal of Business Ethics 84(4):479-495.

Sharma, S., and H. Vredenburg. 1998. Proactive corporate environmental strategy and the development of competitively valuable organizational capabilities. Strategic Management Journal 19(8):729-753. http://dx.doi.org/10.1002/(SICI) 1097-0266(199808)19:8<729::AID-SMJ967>3.0.CO;2-4

Sluyterman, K. 2010. Royal Dutch Shell: company strategies for dealing with environmental issues. Business History Review 84(2):203-226. http://dx.doi.org/10.1017/S0007680500002580

Soares de Oliveira, R. 2007. Oil and politics in the Gulf of Guinea. Columbia University Press, New York, USA.

Sørstrøm, S. E., P. J. Brandvik, I. Buist, P. Daling, D. Dickins, L.-G. Faksness, S. Potter, J. F. Rasmussen, and I. Singsaas. 2010. Joint industry program on oil spill contingency for Arctic and ice-covered waters. SINTEF joint industry program. Oil in Ice Report No.32. [online] URL: http://www. sintef.no/project/JIP Oil In Ice/Dokumenter/publications/JIPrep-no-32-Summary-report.pdf

SustainAbility. 2001. Buried treasure: uncovering the business case for corporate sustainability. SustainAbility and United Nations Environment Programme, London, UK.

SustainAbility. 2002. Developing value: the business case for sustainability in emerging markets. SustainAbility, International Finance Corporation and Ethos, London, UK.

Transparency International. 2008. Promoting revenue transparency - 2008 report on revenue transparency of oil and gas companies. Transparency International, Berlin, Germany.

Uchida, T., and P. J. Ferraro. 2007. Voluntary development of environmental management systems: motivations and 
regulatory implications. Journal of Regulatory Economics 32:37-65. http://dx.doi.org/10.1007/s11149-006-9016-6

United Nations Environment Programme (UNEP). 2011. Environmental assessment of Ogoniland. UNEP, Nairobi, Kenya.

U.S. logs 7 years without massive oil spill. Oil \& Gas Journal 1996. August 19:36.

Utting, P. 2007. CSR and equality. Third World Quarterly 28 (4):697-712. http://dx.doi.org/10.1080/01436590701336572

Van Der Linde, C. 1993. The microeconomic implication of environmental regulation : a preliminary framework. In Environmental policies and industrial competitiveness. OECD, Paris, France.

Waldman, D. A., M. S. de Luque, N. Washburn, R. J. House, B. Adetoun, A. Barrasa, M. Bobina, M. Bodur, Y. Chen, S. Debbarma, P. Dorfman, R. R. Dzuvichu, I. Evcimen, P. Fu, M. Grachev, R. Gonzalez Duarte, V. Gupta, D. N Den Hartog, A. H. B. de Hoogh, J. Howell, K. Jone, H. Kabasakal, E. Konrad, P. L. Koopman, R. Lang, C. Lin, J. Liu, B. Martinez, A. E. Munley, N. Papalexandris, T. K. Peng, L. Prieto, N. Quigley, J. Rajasekar, F. G. Rodríguez, J. Steyrer, B. Tanure, H. Thierry, V. M. Thomas, P. T van den Berg, and C. P. M. Wilderom. 2006. Cultural and leadership predictors of corporate social responsibility values of top management: a GLOBE study of 15 countries. Journal of International Business Studies 37(6):823-837. http://dx.doi.org/10.1057/ palgrave.jibs. 8400230

Wren, J. 2000. Overview of the compensation and liability regimes under the International Oil Pollution Compensation Fund (IOPC). Spill Science \& Technology 6(1):45-58. http:// dx.doi.org/10.1016/S1353-2561(00)00067-0

Yip, T. L., W. K. Talley, and D. Jin. 2011. The effectiveness of double hulls in reducing vessel-accident oil spillage. Marine Pollution Bulletin 62(11):2427-2432. http://dx.doi.org/10.1016/ j.marpolbul.2011.08.026 